\title{
ANALISIS PENILAIAN TINGKAT KESEHATAN BANK PADA PT. BANK SULTENG CAPEM BANGGAI KEPUALAUAN
}

\author{
Heny Ariwijaya \\ Dosen Fakultas Ekonomi Universitas Tompotika Luwuk
}

\begin{abstract}
Abstrak
Tingkat kesehatan bank dapat diartikan sebagai kemampuan suatu bank untuk melakukan kegiatan operasional perbankan secara normal dan mampu memenuhi semua kewajibannya dengan baik dengan cara-cara yang sesuai dengan peraturan perbankan yang berlaku. , pengertian lainnya mengatakan bahwa penilaian tingkat kesehatan bank merupakan hasil penilaian kuantitatif atas berbagai aspek yang berpengaruh terhadap kondisi atau kinerja keuangan bank. Pengertian tentang kesehatan bank ini merupakan tingkat kesehatan bank yang dilakukan secara periodik baik pertahun atau triwulanan.

Yang menjadi permasalahan dalam penelitian ini adalah bagaimana menilai tingkat kesehatan bank pada PT.Bank Sulteng Capem Banggai Kepulauan, sedangkan tujuan dari penelitian ini untuk mengetahui tingkat Kesehatan Bank pada PT. Bank Sulteng Capem Banggai Kepulauan.

Adapun alat analisis yang digunakan dalam penelitian ini didasarkan pada Surat Keputusan Menteri Keuangan Republik Indonesia No. 198/KMK.016/1998 tanggal 24 Maret 1998 dan Peraturan Bank Indonesia No. 6/10/PBI/2004 tentang penilaian tingkat kesehatan bank, yaitu dengan cara menghitung tingkat rasio yang menjadi komponen penilaian, yang meliputi : rasio permodalan, rasio efisiensi usaha, rasio risiko usaha bank, rasio rentabilitas, dan rasio likuiditas.

Berdasarkan hasil penelitian dapat diketahui bahwa penilaian tingkat kesehatan bank pada PT. Bank Sulteng Capem Banggai kepulauan untuk periode tahun 2011 diperoleh bobot penilaian sebesar 70 dengan kategori atau predikat Cukup Sehat, sedangkan untuk periode triwulan pertama tahun 2012 diperoleh bobot penilaian sebesar 61, hasil inipun masuk dalam kategori atau predikat Cukup Sehat, hal ini menggambarkan bahwa kinerja keuangan pada PT. Bank Sulteng Capem Banggai Kepulauan sudah cukup baik.
\end{abstract}

Kata Kunci : Kesehatan Bank

\section{Pendahuluan}

Pada perusahaan swasta tidak ada peraturan baku yang mengatur tentang kesehatan atau kinerja perusahaan, sehingga masing-masing perusahaan dan industri menilai berdasar pada pengalaman-pengalaman masa lalunya, dan biasanya yang paling banyak digunakan adalah analisis Likuiditas, Solvabilitas, dan Rentabilitas. Sama seperti halnya Badan Usaha Milik Negara (BUMN), semula dalam menilai kinerjanya juga dengan ketiga alat tersebut diatas. Tetapi semenjak tahun 1998 telah ada pedoman yang mengatur secara rinci penilaian tingkat kesehatan Badan Usaha Milik Negara. Pedoman tersebut tertuang dalam Surat keputusan Menteri Keuangan
Republik Indonesia No. 198/KMK.016/1998 tanggal 24 Mei 1998 tentang Penilaian Tingkat Kesehatan Badan Usaha Milik Negara jasa keuangan dan Non jasa keuangan. Untuk melengkapi surat keputusan tersebut khususnya pada sector perbankan Bank Indonesia mengeluarkan Peraturan Bank Indonesia No.6/10/ PBI/2004 pada tanggal 12 April 2004 menjelaskan tentang tingkat kesehatan bank secara periodik baik pertahun atau triwulanan, merupakan hasil penilaian kuantitatif atas berbagai aspek yang berpengaruh terhadap kondisi atau kinerja bank tertentu.

Saat ini aktivitas dan jasa-jasa bank berkembang sangat pesat dibandingkan dengan masa awal perkembangan perbankan nasional. 
Deregulasi keuangan yang dilakukan pemerintah membuat lembaga keuangan khususnya perbankan mengalami perubahan kearah yang jauh lebih baik dengan tingkat kepuasan layanan yang tinggi. Bank menjadi sangat dekat dengan masyarakat dan sangat membantu aktivitas keuangan mereka.

PT. Bank Sulteng Capem Banggai Kepulauan adalah Badan Usaha Milik Negara Jasa Keuangan yang bergerak dibidang perbankan dan sangat berpengaruh terhadap kelangsungan aktifitas sehari-hari seluruh masyarakat yang ada khususnya di Kabupaten Banggai sehingga sangat penting diketahui kondisi kesehatannya.

Berdasarkan observasi yang penulis lakukan dilapangan bahwa kondisi keuangan PT. Bank Sulteng Capem Banggai Kepulauan pada tiga tahun terakhir semakin meningkat, dimana pada setiap tahunnya keuntungan yang diperoleh PT. Bank Sulteng Capem Banggai Kepulauan semakin besar. Hal ini dikarenakan

\section{Metode Penelitian. Metode Analisis}

Dari perumusan masalah yang penulis kemukakan terdahulu yaitu mengenai Penilaian Tingkat Kesehatan Bank pada PT. Bank Sulteng Capem Banggai Kepulauan , maka alat analisis yang digunakan pada penelitian ini didasarkan pada Surat Keputusan Menteri Keuangan kinerja keuangan pada PT. Bank Sulteng Capem Banggai Kepulauan terus menerus meningkat setiap tahunnya.

Menyadari arti pentingnya kesehatan suatu bank bagi pembentukan kepercayaan dalam dunia perbankan serta untuk melaksanakn prinsip kehati-hatian bagi para nasabah maka penulis tertarik untuk meneliti tentang : "Analisis Penilaian Tingkat Kesehatan Bank pada PT. Bank Sulteng Capem Banggai Kepulauan ".

\section{Rumusan Masalah}

Perumusan masalah yang ada pada penelitian ini yang didasarkan pada latar belakang diatas adalah sebagai berikut :

"Bagaimanakah Tingkat Kesehatan Bank pada PT. Bank Sulteng Capem Banggai Kepulauan dilihat dari Aspek Keuangan ?’.

Tujuan Penelitian : tujuan dari penelitian ini adalah untuk mengetahui tingkat Kesehatan Bank pada PT. Bank Sulteng Capem Banggai Kepulauan

Republik Indonesia No. 198/KMK.016/1998 tanggal 24 Maret 1998 dan Peraturan Bank Indonesia No. 6/10/PBI/2004

Adapun tingkat kesehatan bank ditetapkan berdasarkan penilaian terhadap kinerja keuangan untuk tahun buku yang bersangkutan, dan indikator alat analisis yang dinilai dan masing-masing bobot adalah sebagai berikut :

1. Rasio Permodalan :

a. Capital Adequacy Ratio (CAR) :

$$
\text { Equity Capital }
$$

Total Loans

Dengan ketentuan nilai bobot yang diberikan untuk hasil perhitungan Rasio diatas yang besarnya diatur sebagai berikut : 
Tabel 1 Nilai Bobot Rasio

\begin{tabular}{|l|c|}
\hline \multicolumn{1}{|c|}{ Nilai Rasio (\%) } & Nilai Bobot \\
\hline $5<$ Rasio & 10 \\
$4<$ Rasio $\leq 4,99$ & 8,5 \\
$3<$ Rasio $\leq 3,99$ & 7 \\
$2<$ Rasio $\leq 2,99$ & 5,5 \\
$1<$ Rasio $\leq 1,99$ & 4 \\
$0<$ Rasio $\leq 0,99$ & 2,5 \\
\hline \multicolumn{2}{|c|}{ Sumber $:$ SK Menteri keuangan dan Peraturan BI(Sutrisno.2001) }
\end{tabular}

b. Current Liabilities to Equity (CLE)

$$
\frac{\text { Utang Lancar }}{\text { Ekuitas }}
$$

Dengan ketentuan nilai bobot yang diberikan untuk hasil perhitungan Rasio diatas yang besarnya diatur sebagai berikut :

Tabel 2 Nilai Bobot Rasio

\begin{tabular}{|c|c|c|}
\hline \multicolumn{2}{|r|}{ Nilai Rasio (\%) } & Nilai Bobot \\
\hline 10 & $<$ Rasio & 10 \\
\hline 8 & $<$ Rasio $\leq 9,99$ & 8,5 \\
\hline 6 & $<$ Rasio $\leq 7,99$ & 7 \\
\hline 4 & $<$ Rasio $\leq 5,99$ & 5,5 \\
\hline 2 & $<$ Rasio $\leq 3,99$ & 4 \\
\hline 0 & $<$ Rasio $\leq 1,99$ & 2,5 \\
\hline
\end{tabular}

2. Rasio Efisiensi Usaha

a. Leverage Multiplier Ratio (LMR)

$$
\text { LMR }=\frac{\text { Total Assets }}{\text { Total Equity Capital }}
$$

Dengan ketentuan nilai bobot yang diberikan untuk hasil perhitungan rasio diatas yang besarnya diatur sebagai berikut :

Tabel 3 Nilai Bobot Rasio

\begin{tabular}{|l|c|}
\hline \multicolumn{1}{|c|}{ Nilai Rasio (\%) } & Nilai Bobot \\
\hline $5<$ Rasio & 2,5 \\
$4<$ Rasio $\leq 4,99$ & 4 \\
$3<$ Rasio $\leq 3,99$ & 5,5 \\
$2<$ Rasio $\leq 2,99$ & 7 \\
$1<$ Rasio $\leq 1,99$ & 8,5 \\
$0<$ Rasio $\leq 0,99$ & 10 \\
\hline \multicolumn{2}{|c|}{ Sumber : SK Menteri keuangan dan Peraturan BI(Sutrisno.2001) }
\end{tabular}

b. Costs of Money (CM)

\section{Total Biaya Dana + Overhead Expense}

\section{Total Dana}

Dengan ketentuan nilai bobot yang diberikan untuk hasil perhitungan rasio diatas yang besarnya diatur sebagai berikut : 
Tabel 4 Nilai Bobot Rasio

\begin{tabular}{|c|c|}
\hline Nilai Rasio (\%) & Nilai Bobot \\
\hline $5<$ Rasio & 10 \\
\hline $4<$ Rasio $\leq 4,99$ & 8,5 \\
\hline $3<$ Rasio $\leq 3,99$ & 7 \\
\hline $2<$ Rasio $\leq 2,99$ & 5,5 \\
\hline $1<$ Rasio $\leq 1,99$ & 4 \\
\hline $0 \quad$ Rasio $\leq 0,99$ & 2,5 \\
\hline
\end{tabular}

3. Rasio Risiko Usaha Bank

a. Deposit Risk Ratio (DRR)

\section{Equity Capital \\ Total Deposits}

Dengan ketentuan nilai bobot yang diberikan untuk hasil perhitungan Rasio diatas yang besarnya diatur sebagai berikut :

Tabel 5 Nilai Bobot Rasio

\begin{tabular}{|c|c|c|}
\hline \multicolumn{2}{|r|}{ Nilai Rasio (\%) } & Nilai Bobot \\
\hline 5 & Rasio & 10 \\
\hline 4 & Rasio $\leq 4,99$ & 8,5 \\
\hline 3 & Rasio $\leq 3,99$ & 7 \\
\hline 2 & Rasio $\leq 2,99$ & 5,5 \\
\hline 1 & Rasio $\leq 1,99$ & 4 \\
\hline 0 & Rasio $\leq 0,99$ & 2,5 \\
\hline
\end{tabular}

b. Interest Rate Risk Ratio (IRRR)

\section{Interest Sensitivity Asssets \\ Interest Sensitivity Liabilities}

Dengan ketentuan nilai bobot yang diberikan untuk hasil perhitungan rasio diatas yang besarnya diatur sebagai berikut :

Tabel 6 Nilai Bobot Rasio

\begin{tabular}{|c|c|}
\hline Nilai Rasio (\%) & Nilai Bobot \\
\hline $5<$ Rasio & 10 \\
\hline $4<$ Rasio $\leq 4,99$ & 8,5 \\
\hline $3<$ Rasio $\leq 3,99$ & 7 \\
\hline $2<$ Rasio $\leq 2,99$ & 5,5 \\
\hline $1<$ Rasio $\leq 1,99$ & 4 \\
\hline $0<$ Rasio $\leq 0,99$ & 2,5 \\
\hline
\end{tabular}


4. Rasio Rentabilitas

a. Return on Assets (ROA)

Operating Income

Total Assets

Dengan ketentuan nilai bobot yang diberikan untuk hasil perhitungan Rasio diatas yang besarnya diatur sebagai berikut :

Tabel 7 Nilai Bobot Rasio

\begin{tabular}{|c|c|c|}
\hline \multicolumn{2}{|r|}{ Nilai Rasio (\%) } & Nilai Bobot \\
\hline 5 & Rasio & 10 \\
\hline & Rasio $\leq 4,99$ & 8,5 \\
\hline & Rasio $\leq 3,99$ & 7 \\
\hline 2 & Rasio $\leq 2,99$ & 5,5 \\
\hline & Rasio $\leq 1,99$ & 4 \\
\hline & Rasio $\leq 0,99$ & 2,5 \\
\hline
\end{tabular}

b. Interest Margin on Loans (IML)

Interest Income - Interest Expense

\section{Total Loans}

Dengan ketentuan nilai bobot yang diberikan untuk hasil perhitungan rasio diatas yang besarnya diatur sebagai berikut :

Tabel 8 Nilai Bobot Rasio

\begin{tabular}{|c|c|c|}
\hline \multicolumn{2}{|r|}{ Nilai Rasio (\%) } & Nilai Bobot \\
\hline & $<$ Rasio & 10 \\
\hline 2 & $<$ Rasio $\leq 4,99$ & 8,5 \\
\hline 3 & $<$ Rasio $\leq 3,99$ & 7 \\
\hline 2 & $<$ Rasio $\leq 2,99$ & 5,5 \\
\hline 1 & $<$ Rasio $\leq 1,99$ & 4 \\
\hline( & $<$ Rasio $\leq 0,99$ & 2,5 \\
\hline
\end{tabular}

5. Rasio Likuiditas

a. Quick Ratio (QR)

Aktiva Lancar

Utang Lancar/Kewajiban Jangka Pendek

Dengan ketentuan nilai bobot yang diberikan untuk hasil perhitungan Rasio diatas yang besarnya diatur sebagai berikut : 
Tabel 9 Nilai Bobot Rasio

\begin{tabular}{|c|c|c|}
\hline \multicolumn{2}{|r|}{ Nilai Rasio (\%) } & Nilai Bobot \\
\hline 4 & Rasio & 10 \\
\hline 3 & Rasio $\leq 3,99$ & 8,5 \\
\hline 2 & Rasio $\leq 2,99$ & 7 \\
\hline 1 & Rasio $\leq 1,99$ & 5,5 \\
\hline 0 & Rasio $\leq 0,99$ & 4 \\
\hline & Rasio $\leq 0$ & 2,5 \\
\hline
\end{tabular}

b. Loan Deposits to Ratio (LDR)

Utang Lancar/Kewajiban Jangka Pendek

Giro + Tabungan + Deposits

Dengan ketentuan nilai bobot yang diberikan untuk hasil perhitungan rasio diatas yang besarnya diatur sebagai berikut :

Tabel 10 Nilai Bobot Rasio

\begin{tabular}{|c|c|}
\hline Nilai Rasio (\%) & Nilai Bobot \\
\hline $50<$ Rasio & 10 \\
$40<$ Rasio $\leq 49,99$ & 8,5 \\
$30<$ Rasio $\leq 39,99$ & 7 \\
$20<$ Rasio $\leq 29,99$ & 5,5 \\
$10<$ Rasio $\leq 19,99$ & 4 \\
$0 \leq$ Rasio $\leq 09,99$ & 2,5 \\
\hline \multicolumn{2}{|c|}{ Sumber $:$ SK Menteri keuangan dan Peraturan BI(Sutrisno.2001) }
\end{tabular}

Berdasarkan alat analisis diatas, sesuai dengan Keputusan Menteri Keuangan No. 198/KMK.016/1998 tentang Penilaian Tingkat Kesehatan BUMN dan Peraturan Bank Indonesia No.6 / 10 / PBI / 2004 (Arthesa,Handiman.2006 : 132) maka predikat tingkat kesehatan bank berdasarkan nilai bobot yang diperoleh, yaitu :

Tabel. 11 Predikat Kesehatan Perbankan

\begin{tabular}{|c|l|c|}
\hline NO & \multicolumn{1}{|c|}{ PREDIKAT } & NILAI BOBOT \\
\hline 1. & SEHAT & 81 S/D 100 \\
2. & CUKUP SEHAT & 61 S/D 80 \\
3. & KURANG SEHAT & 41 S/D 60 \\
4. & TIDAK SEHAT & 00 S/D 40 \\
\hline
\end{tabular}

Sumber : Bank Indonesia (Sawir,2001:44)

\section{Hasil Penelitian dan Pebahasan} Analisis Hasil Penelitian.

Berdasarkan rumusan masalah dalam penelitian ini yaitu bagaimana menilai tingkat kesehatan PT. Bank Sulteng Capem Banggai Kepulauan dari aspek keuangan, penulis menggunakan alat analisis berdasarkan Surat
Keputusan Menteri Keuangan No. 198/KMK.016/1998, dan Peraturan Bank Indonesia No.6 / 10 / PBI / 2004 yang telah penulis kemukakan pada bab sebelumnya, yang mana penelitian ini dilakukan dengan cara menilai atau mengkaji langsung data keuangan perusahaan tahun sebelumnya yakni tahun 2010 
dan data keuangan tahun berjalan yakni triwulan pertama tahun 2011.

Dari hasil penelitian ini, penulis bermaksud untuk mengkaji atau memproses data keuangan yang penulis dapatkan dari tempat penelitian yakni berupa laporan keuangan konsolidasi PT. Bank Sulteng Cabang Luwuk dan, yang terdiri dari Neraca dan Laporan Rugi laba periode 2010 dan Triwulan I tahun 2011, seperti terlihat pada tabel 12 dibawah ini :

\section{PT.BANK SULTENG CAPEM BANGKEP N E R A C A \\ 31 DESEMBER 2011 \& TRIWULAN I 2012}

\begin{tabular}{|c|c|c|}
\hline POS - POS & 2011 & TRI.I 2012 \\
\hline \multicolumn{3}{|l|}{ AKTIVA } \\
\hline Kas Besar & 6.153 .576 .400 & 1.551.741.000 \\
\hline Giro Bank BNI 46 & 10.500.000.000 & 25.750 .500 .000 \\
\hline Giro Bank BRI & 3.450 .789 .560 & 5.485 .500 .000 \\
\hline Giro Bank Mandiri & 1.115.250.000 & 3.658.450.725 \\
\hline Giro Bank Panin & 1.000 .000 .000 & 1.000.000.000 \\
\hline Giro Pemerintah Daerah & 150.000 .000 & 90.000 .000 \\
\hline Giro Dinas-Dinas Pemda & 125.000 .000 & 100.750 .000 \\
\hline Giro Pihak ketiga & 6.916.667.617,46 & 24.602.294.780,66 \\
\hline Deposito Bank BNI 46 & 256.200 .000 & 256.200 .000 \\
\hline Deposito Bank BRI & 285.750 .560 & 285.750 .560 \\
\hline Deposito Bank Mandiri & 498.650 .000 & 498.650 .000 \\
\hline Deposito Bank Panin & 185.650 .250 & 185.650 .250 \\
\hline Deposito Pihak Ketiga & 16.249 .190 & 16.249 .190 \\
\hline KMK Jangka Pendek & 1.263.450.000 & 355.250 .000 \\
\hline KMK Jangka Menengah/panjang & 2.568.565.700 & 450.654 .750 \\
\hline KUMK - Mikro Jangka pendek & 950.789 .450 & 158.658 .650 \\
\hline KUMK - Mikro Jangka Menengah & 2.250.250.000 & 789.890 .500 \\
\hline Kredit Pegawai jangka panjang & 2.985.750.000 & 1.000.000.000 \\
\hline Kredit Pegawai BPD & 850.650 .250 & 545.800 .650 \\
\hline KI Jangka pendek & 1.865.756.250 & 255.985 .000 \\
\hline KI jangka panjang & $9.202 .005 .462,72$ & 1.063.572.161 \\
\hline Cadangan Umum PPAP kredit & $(373.787 .110,50)$ & $(125.555 .685,50)$ \\
\hline Cadangan Umum PPAP Dana & $(24.513 .363,56)$ & $(14.250 .685,40)$ \\
\hline $\begin{array}{l}\text { Cadangan Khusus PPAP kredit yang } \\
\text { diberikan }\end{array}$ & $(8.639 .656 .563,72)$ & $(1.988 .785 .256,65)$ \\
\hline Persediaan Brg Cetakan \& formulir & 25.646 .500 & 11.750 .250 \\
\hline Persediaan ATK & 27.251 .000 & 14.895 .625 \\
\hline Persediaan Buku Cek \& Bilyet Giro & 29.650 .000 & 16.585 .750 \\
\hline AKTIVA TETAP & & \\
\hline Harga perolehan & 1.255.850.000 & 1.255.850.000 \\
\hline Akumulasi Penyusutan & $(865.789 .650,45)$ & $(965.789 .650,45)$ \\
\hline Nilai Buku & $390.060 .349,55$ & $290.060 .349,55$ \\
\hline TOTAL AKTIVA & 151.152.077.777,33 & $224.951 .985 .435,75$ \\
\hline
\end{tabular}




\begin{tabular}{|l|r|r|}
\hline PASSIVA & & \\
PYMADIT-KMK-jangka pendek & & \\
PYMADIT-KMK-jangka meneng/pjg & 780.850 .890 & 906.500 .890 \\
PYMADIT-KUMK-MIKRO-SUP005 & 3.560 .789 .950 & 3.560 .789 .950 \\
PYMADIT-KI-jangka men/pjg & 1.256 .777 .850 & 1.256 .777 .850 \\
PYMADIT-Kredit pegawai men/pjg & 4.568 .985 .000 & 4.568 .985 .000 \\
Giro Pemerintah Daerah & 850.560 .625 & 850.560 .625 \\
Giro Dinas-Dinas Pemda & 5.456 .850 .250 & 5.456 .850 .250 \\
Giro Perusahaan Daerah/BUMD & 3.895 .275 .100 & 3.895 .275 .100 \\
Giro Perusahaan Swasta & 3.650 .185 .500 & 3.650 .185 .500 \\
Giro perusahaan asuransi swata & 1.970 .250 .320 & 1.970 .250 .320 \\
Giro Lain-lain & 985.870 .500 & 985.870 .500 \\
Tabungan simpeda & 2.650 .330 .450 & 2.650 .330 .450 \\
Tabungan Lokal & 1.966 .350 .450 & 2.316 .350 .450 \\
Titipan pihak ke III Angs pinjaman & 1.565 .711 .899 & 1.881 .932 .079 \\
Titipan penampungan selisih & 550.265 .750 & 550.265 .750 \\
Titipan Intern & 450.900 .450 & 450.900 .450 \\
Pokok pendanaan KUMK & 580.855 .200 & 580.855 .200 \\
Jumlah Passiva Lancar & $956.114 .260,40$ & $956.114 .260,40$ \\
Kewajiban dari bank lain & $35.969 .924 .444,40$ & $36.488 .794 .624,40$ \\
Kewajiban Pihak ke III & 15.656 .495 .600 & 15.656 .495 .600 \\
Kewajiban lain-lain & 6.987 .235 .300 & 6.987 .235 .300 \\
TOTAL KEWAJIBAN & 2.083 .269 .100 & 2.083 .269 .100 \\
MODAL/EKUITAS & $60.696 .924 .444,40$ & $61.488 .794 .624,40$ \\
Modal di setor & & \\
\hline TOTAL PASSIVA & & \\
\hline
\end{tabular}

Sumber : PT.Bank Sulteng Capem Bangkep

Tabel 13

PT.BANK SULTENG CAPEM BANGKEP

LAPORAN RUGI/LABA

31 DESEMBER 2011 \& TRIWULAN I 2012

\begin{tabular}{|l|r|r|}
\hline \multicolumn{1}{|c|}{ POS - POS } & \multicolumn{1}{c|}{$\mathbf{2 0 1 1}$} & \multicolumn{1}{|c|}{ TRI.I 2012 } \\
\hline Pendapatan Bunga : & $312.562 .750,25$ & $142.706 .896,04$ \\
Pendapatan bunga jasa giro & $290.889 .653,45$ & $85.068 .496,14$ \\
Pendapatan bunga deposito & $1.165 .865 .750,55$ & $175.784 .981,39$ \\
Pendapatan bunga KMK & $388.951 .600,50$ & $45.940 .080,44$ \\
Pendapatan bunga KUMK & $245.230 .650,56$ & $76.121 .373,98$ \\
Pendapatan bunga KI Mikro & $2.556 .854 .511,75$ & $280.556 .854,75$ \\
Pendapatan Bunga Pegawai & $482.230 .986,41$ & $82.450 .986,48$ \\
Pendapatan bunga antar kantor & $\underline{403.003 .693,59}$ & $97.939 .897,69$ \\
Pendapatan provisi kredit & $5.645 .589 .597,06$ & $986.569 .566,91$ \\
Total Pendapatan Bunga : & & \\
Beban bunga dan pembayaran lainnya. & & \\
\hline
\end{tabular}




\begin{tabular}{|c|c|c|}
\hline Pendapatan bunga bersih & $\frac{4.789 .544 .312,63}{856.045 .284,43}$ & $\frac{693.182 .758,10}{293.386 .808,81}$ \\
\hline Pendapatan Operasional lainnya : & & \\
\hline Pendapatan jasa giro Pemda & 2.756.230.000,41 & $355.155 .350,34$ \\
\hline Pendapatan Jasa giro Dinas-Dinas & $1.650 .241 .900,85$ & $122.523 .400,88$ \\
\hline Pendapatan jasa giro BUMD & $950.852 .457,85$ & 289.653.124,51 \\
\hline Pendapatan jasa giro Perusahaan & $766.584 .650,50$ & $234.550 .643,64$ \\
\hline Pendapatan jasa giro lain-lain & $556.621 .740,25$ & $65.235 .850,21$ \\
\hline Pendapatan Administrasi lainnya & $965.058 .847,20$ & $119.451 .197,33$ \\
\hline Total Pendapatan Operasional & $7 . \overline{645.589 .597,06}$ & $1 . \overline{186.569 .566,91}$ \\
\hline Beban operasional lainnya & & \\
\hline Beban Umum \& Administrasi & 1.875 .235 .500 & 168.750 .563 \\
\hline Beban Gaji dan Kesejahteraan karyawan & 2.765 .850 .000 & 485.890 .560 \\
\hline Beban Non Operasional : & & \\
\hline Amortisasi penyelamatan bank & 846.950 .700 & 136.640 .600 \\
\hline Pajak Penghasilan & $\underline{551.508 .112,63}$ & $\underline{101.901 .035 .10}$ \\
\hline Total Beban Opersi \& Non Opera. & 6.039 .544 .312 .63 & $893.182 .758,10$ \\
\hline Pendapatan Operasional Bersih & $1.606 .045 .284,43$ & 293.386.808.81 \\
\hline Laba Bersih & $2.462 .090 .568,86$ & $586.773 .617,22$ \\
\hline
\end{tabular}

Untuk lebih memudahkan penulis memfokuskan rekening - rekening penguraiaan pembahasan ini, dan agar atau komponen - komponen mana saja lebih mudah diketahui rumus yang yang masuk dalam penelitian ini, seperti digunakan dalam analisis tersebut, maka terlihat pada tabel 14 dibawah ini :

Tabel 14

Data Posisi Keuangan PT. Bank Sulteng Capem Banggai Kepulauan periode tahun 2011 dan Triwulan I tahun 2012

\begin{tabular}{|l|r|r|}
\hline \multicolumn{1}{|c|}{ Uraian } & \multicolumn{1}{|c|}{2011} & \multicolumn{1}{c|}{$\begin{array}{c}2012 \\
\text { Triwulan I }\end{array}$} \\
\hline 1. Total Aktiva/Passiva & $154.152 .077 .777,33$ & $224.951 .985 .435,75$ \\
2. Kas & 6.153 .576 .400 & $1.551 .741 .000 .-$ \\
3. Giro & $23.257 .707 .177,46$ & $60.687 .495 .505,66$ \\
4. Tabungan & 12.172 .862 .751 & 4.619 .811 .711 \\
5. Deposito & 1.242 .500 .000 & 1.242 .500 .000 \\
6. Kewajiban jangka pendek & $35.696 .924 .444,40$ & $36.488 .794 .624,40$ \\
7. Total Kewajiban (Loans) & $60.696 .924 .444,40$ & $61.488 .794 .624,40$ \\
8. Modal (Equity) & $93.455 .153 .332,93$ & $163.463 .190 .811,35$ \\
9. Pendapatan bunga & $5.645 .589 .597,06$ & $986.569 .566,91$ \\
10. Biaya bunga & $4.789 .544 .312,63$ & $693.182 .758,10$ \\
11. Total Biaya & $6.039 .544 .312,63$ & $893.182 .758,10$ \\
12. Pendapatan operasional & $7.645 .589 .597,06$ & $1.186 .569 .566,91$ \\
\hline \multicolumn{2}{|c|}{ Sumber : Data Keuangan PT. Bank Sulteng Capem Banggai Kepulauan }
\end{tabular}




\section{Pembahasan Hasil Penelitian}

Sesuai dengan alat analisis yang digunakan, yaitu berdasarkan Surat Keputusan Menteri Keuangan No. 198/KMK.016/1998, dan Peraturan Bank Indonesia No.6 / 10 / PBI / 2004 , maka untuk menentukan cara menilai tingkat kesehatan Bank pada PT. Bank Sulteng

1. Rasio Permodalan :

a. Capital Adequacy Ratio (CAR) : rasio ini digunakan untuk mengukur kemampuan permodalan yang ada untuk menutup kemungkinan kerugian didalam kegiatan perkreditan, adapun perhitungannya adalah sebagai berikut :

\section{Equity Capital}

Total Loans

Dari data dapat diketahui bahwa :

1. Periode Tahun 2011 Equity capital (modal) :

Rp. 93.455.153.332,93 dan Total Loans (kewajiban) :

Rp. 60.696.924.444,40. Maka CAR tahun 2011 adalah sebagai berikut :

$$
\mathrm{CAR}=\frac{\mathrm{Rp} \cdot 93 \cdot 455 \cdot 153 \cdot 332,93_{-}}{\text {Rp. 60.696.924.444,40 }}=1,539 \%
$$

Dari hasil perhitungan ini diperoleh tingkat capital adequacy ratio untuk periode tahun 2011 sebesar 1,539 \%, ini menunjukkan bahwa setiap Rp.1 kewajiban akan dijamin oleh modal sebesar Rp.1,539 sehingga semakin tinggi tingkat rasio CAR semakin baik pula tingkat permodalan perusahaan.

2. Periode Triwulan I Tahun 2012 Equity capital (modal) :

Rp. 163.463.190.811,35 dan Total Loans (kewajiban) :

Rp. 61.488.794.624,40. Maka CAR tahun 2012 Triwulan I adalah sebagai berikut :

$$
\mathrm{CAR}=\frac{\text { Rp. } 163 \cdot 463 \cdot 190 \cdot 811,35}{\text { Rp. 61.488.794.624,40 }}=2,658 \%
$$

Dari hasil perhitungan ini menunjukkan bahwa setiap kewajiban sebesar Rp.1 akan dijamin oleh modal sebesar Rp.2,658 berdasarkan hasil ini maka dapat diketahui capital adequacy ratio triwulan I tahun 2012 lebih besar dari tahun 2011, hal ini menunjukkan adanya peningkatan tingkat rasio dari tahun sebelumnya.

b. Current Liabilities to Equity (CLE) : Rasio ini untuk mengetahui berapa besar perbandingan antara utang lancar dengan equitas suatu bank. Adapun perhitungannya adalah sebagai berikut

$$
\underline{\text { Utang Lancar }}
$$

\section{Ekuitas}


Dari data diketahui bahwa :

1. Periode Tahun 2011 Utang Lancar sebesar: Rp. 35.696.924.444,40 dan ekuitas (modal) : Rp. 93.455.153.332,93 Maka CLE tahun 2011 adalah sebagai berikut :

$$
\mathrm{CLE}=\frac{\text { Rp. } 35 \cdot 696 \cdot 924 \cdot 444,40}{\text { Rp. 93.455.153.332,93 }}=0,382 \times 100=38,2 \%
$$

Dari hasil perhitungan ini diperoleh tingkat rasio current liabilities to equity tahun 2011 sebesar 38,2 \%, hal ini menunjukkan bahwa setiap Rp.1 kewajiban hutang lancar akan dijamin oleh modal sebesar Rp.38,2 sehingga dapat disimpulkan bahwa semakin tinggi tingkat rasio semakin besar pula permodalan perusahaan.

2. Periode Triwulan I Tahun 2012 Utang Lancar sebesar :

Rp. 36.488.794.624,40 dan ekuitas (modal) :

Rp. 163.463.190.811,35 Maka CLE tahun 2012 triwulan I adalah sebagai berikut :

$$
\mathrm{CLE}=\frac{\mathrm{Rp} \cdot 36 \cdot 488.794 .624,40}{\text { Rp. } 163.463 .190 .811,35}=0,223 \times 100=22,3 \%
$$

Dari hasil perhitungan ini diperoleh tingkat rasio current liabilities to equity triwulan I tahun 2012 sebesar 22,3 \%, hal ini menunjukkan bahwa setiap Rp.1 kewajiban hutang lancar akan dijamin oleh modal sebesar Rp.22,3.-

\section{Rasio Efisiensi Usaha}

a. Leverage Multiplier Ratio (LMR) : Rasio ini untuk mengukur kemampuan manajemen bank didalam mengelola aktiva yang dikuasainya, adapun perhitungannya adalah sebagai berikut :

$$
\frac{\text { Total Assets }}{\text { Total Equity Capital }}
$$

Dari data diketahui bahwa :

1. Periode Tahun 2011 Total Assets (Aktiva): Rp.154.152.077.777,33 dan Total Equity (modal) :

Rp. 93.455.153.332,93 Maka LMR tahun 2011 adalah sebagai berikut :

$$
\begin{aligned}
& \mathrm{LMR}=\mathrm{Rp} .154 \cdot 152 \cdot 077.777,33=1,649 \% \\
& \text { Rp. 93.455.153.332,93 }
\end{aligned}
$$

Dari hasil perhitungan ini dapat diketahui bahwa tingkat rasio leverage multiplier ratio periode tahun 2011 sebesar 1,649 \% artinya bahwa setiap Rp.1 modal perusahaan akan dijamin oleh asset perusahaan sebesar Rp.1,649. Perlu diketahui bahwa semakin rendah tingkat rasio maka semakin efisiensi penggunaan asset perusahaan..

2. Periode Triwulan I Tahun 2012 Total assets (Aktiva) sebesar :

Rp. 224.951.985.435,75 dan total Equity (modal) sebesar :

Rp. 163.463.190.811,35 Maka LMR tahun 2012 triwulan I adalah sebagai berikut : 


$$
\mathrm{LMR}=\frac{\text { Rp. } 224 \cdot 951 \cdot 985 \cdot 435,75}{\text { Rp.163.463.190.811,35 }}=1,376 \%
$$

Dari hasil perhitungan ini dapat diketahui bahwa tingkat rasio leverage multiplier ratio periode triwulan I tahun 2012 sebesar 1,376 \% artinya bahwa setiap Rp.1 modal perusahaan akan dijamin oleh asset perusahaan sebesar Rp.1,376. Dari hasil ini dapat diketahui tingkat efisiensi periode triwulan I tahun 2012 lebih efisien dari periode tahun 2011.

b. Costs of Money (CM) : Rasio ini untuk mengetahui berapa besarnya biaya rata-rata secara keseluruhan yang digunakan oleh bank untuk dapat mengumpulkan dananya. Adapun perhitungannya adalah sebagai berikut :

$\underline{\text { Total Biaya Dana + Overhead Expense }}$

\section{Total Dana}

Dari data diketahui bahwa :

1. Periode Tahun 2011 total biaya dana dan overhead expense (biaya tenaga kerja dan lain-lain) sebesar Rp. 6.039.544.312,63 dan Total dana (total assets - equity capital) :

Rp. 60.696.924.444,40 Maka CM tahun 2011 adalah sebagai berikut :

$$
\mathrm{CM}=\frac{\text { Rp. } 6 \cdot 039 \cdot 544 \cdot 312,63}{\text { Rp. } 60 \cdot 696 \cdot 924.444,40}=0,099 \times 100=9,9 \%
$$

Dari perhitungan ini diperoleh hasil bahwa tingkat rasio costs of money periode tahun 2011 sebesar 9,9\% artinya bahwa setiap Rp 1 biaya rata-rata yang dikeluarkan pihak bank akan mengumpulkan dana sebesar Rp. 9,9. Semakin tinggi tingkat rasio semakin besar dana yang dikumpulkan.

2. Periode Triwulan I Tahun 2012 total biaya dana dan overhead expense (biaya tenaga kerja dan lain-lain) sebesar

Rp. 893.182.758,10 dan Total dana (total assets-equity capital) : Rp. 61.488.794.624,40 Maka CM tahun 2012 triwulan I adalah sebagai berikut :

$$
\mathrm{CM}=\frac{\text { Rp. } 893 \cdot 182 \cdot 758,10}{\text { Rp. } 61 \cdot 488 \cdot 794 \cdot 624,40}=0,014 \times 100=1,4 \%
$$

Dari perhitungan ini diperoleh hasil bahwa tingkat rasio costs of money periode triwulan Itahun 2012 sebesar 1,4 \% artinya bahwa setiap Rp 1 biaya rata-rata yang dikeluarkan pihak bank akan mengumpulkan dana sebesar Rp. 1,4.

\section{Rasio Risiko Usaha Bank}

a. Deposit Risk Ratio (DRR) : Rasio ini memperlihatkan risiko yang menunjukkan kemungkinan kegagalan bank dalam memenuhi kewajiban kepada para nasabah yang menyimpan dananya yang diukur dengan jumlah permodalan yang dimiliki olah bank, dimana total deposits adalah kewajiban jangka pendek bank berupa total baki debet kredit. Adapun perhitungannya sebagai berikut : 


\section{Equity Capital}

Total Deposits

Dari data diketahui bahwa :

1. Periode Tahun 2011 Equity capital (modal): Rp.93.455.153.332,93 dan Total deposits :

Rp. 35.696.924.444,40 Maka DRR tahun 2011 adalah sebagai berikut :

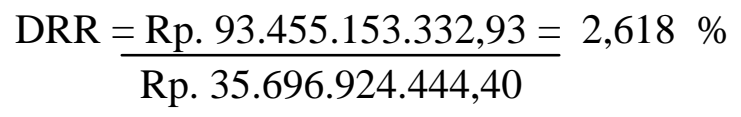

Dari perhitungan ini diperoleh hasil bahwa tingkat deposits risk ratio periode tahun 2011 sebesar 2,618 \% artinya bahwa setiap Rp 1 kewajiban jangka pendek pihak bank akan dibiayai atau kecukupan modal sebesar Rp.2,618. Dalam hal ini semakin besar tingkat rasio, semakin kecil risiko yang ditanggung pihak bank

2. Periode Triwulan I Tahun 2012 Equity capital (modal) sebesar :

Rp. 163.463.190.811,35 dan total deposits sebesar :

Rp. 36.488.794.624,40 Maka DRR tahun 2012 triwulan I adalah sebagai berikut :

$$
\text { DRR }=\frac{\text { Rp. 163.463.190.811,35 }}{\text { Rp. 36.488.794.624,40 }}=4,479 \%
$$

Dari perhitungan ini diperoleh hasil bahwa tingkat deposits risk ratio periode triwulan I tahun 2012 sebesar 4,479 \% artinya bahwa setiap Rp 1 kewajiban jangka pendek pihak bank akan dibiayai atau kecukupan modal sebesar Rp.4,479.

b. Interest Rate Risk Ratio (IRRR) : Rasio ini memperlihatkan risiko yang mengukur kemungkinan interest (bunga) yang diterima oleh bank lebih kecil dibandingkan dengan interest yang dibayar oleh bank, dimana interest sensitivity assets yaitu interest income atau pendapatan bunga dan interest sensitivity liabilities yaitu interest expense atau biaya bunga, adapun perhitungannya adalah sebagai berikut :

$$
\frac{\text { Interest Sensitivity Asssets }}{\text { Interest Sensitivity Liabilities }}
$$

Dari data diketahui bahwa :

1. Periode Tahun 2011 interest income atau pendapatan bunga sebesar Rp. 5.645.589.597,06 dan interest expense atau biaya bunga : Rp.4.789.544.312,63 Maka IRRR tahun 2011 adalah sebagai berikut:

$$
\mathrm{IRRR}=\frac{\text { Rp. } 5 \cdot 645 \cdot 589 \cdot 597,06}{\text { Rp. } 4 \cdot 789.544 \cdot 312,63}=1,178 \%
$$

Dari perhitungan ini diperoleh hasil bahwa tingkat rate risk ratio periode tahun 2011 sebesar 1,178 \% artinya bahwa setiap Rp 1 biaya bunga akan dijamin oleh pendapatan bunga sebesar Rp.1,178. Dalam rasio ini semakin besar tingkat rasio, semakin kecil risiko yang ditanggung pihak bank 
2. Periode Triwulan I Tahun 2012 interest income atau pendapatan bunga sebesar : Rp. 986.569.566,91 dan interest expense atau biaya bunga sebesar : Rp. 693.182.758,10 Maka IRRR tahun 2012 triwulan I adalah sebagai berikut :

$$
\operatorname{IRRR}=\frac{\text { Rp. } 986 \cdot 569 \cdot 566,91}{\text { Rp. 693.182.758,10 }}=1,423 \%
$$

Dari perhitungan ini diperoleh hasil bahwa tingkat rate risk ratio periode triwulan I tahun 2012 sebesar 1,423\% artinya bahwa setiap Rp 1 biaya bunga akan dijamin oleh pendapatan bunga sebesar Rp.1,423. Dalam rasio ini semakin besar tingkat rasio, semakin kecil risiko yang ditanggung pihak bank.

4. Rasio Rentabilitas

a. Return on Assets (ROA) : Rasio ini untuk mengukur kemampuan manajemen bank dalam mengelola aktiva yang dimilikinya untuk menghasilkan berbagai pendapatan, adapun perhitungannya adalah sebagai berikut :

Operating Income

\section{Total Assets}

Dari data diketahui bahwa :

1. Periode Tahun 2011 operating income atau pendapatan operasional sebesar Rp. 7.645.589.597,06 dan total assets atau aktiva : Rp.154.152.077.777,33 Maka ROA tahun 2011 adalah sebagai berikut :

$$
\mathrm{ROA}=\frac{\mathrm{Rp} \cdot 7 \cdot 645 \cdot 589 \cdot 597,06}{\text { Rp. 154.152.077.777,33 }}=0,049 \times 100=4,9 \%
$$

Dari perhitungan ini diperoleh hasil bahwa tingkat rasio return on assets (ROA) periode tahun 2011 sebesar 4,9 \% artinya bahwa kemampuan pihak bank untuk memperoleh keuntungan dengan menggunakan seluruh asset/aktiva sebesar 4,9\%. Dalam rasio ini semakin besar tingkat rasio, semakin besar keuntungan yang diperoleh pihak bank

2. Periode Triwulan I Tahun 2012 operating income atau pendapatan operasional sebesar : Rp. 1.186.569.566,91 dan total assets atau aktiva sebesar : Rp. 224.951.985.435,75 Maka ROA tahun 2012 triwulan I adalah sebagai berikut :

$$
\text { ROA }=\frac{\text { Rp. } 1 \cdot 186 \cdot 569 \cdot 566,91}{\text { Rp. 224.951.985.435,75 }}=0,0052 \times 100=0,52 \%
$$

Dari perhitungan ini diperoleh hasil bahwa tingkat rasio return on assets (ROA) periode triwulan I tahun 2012 sebesar 0,52 \% artinya bahwa kemampuan pihak bank untuk memperoleh keuntungan dengan menggunakan seluruh asset/aktiva sebesar 0,25 $\%$. 
b. Interest Margin on Loans (IML) : Rasio ini untuk mengukur kemampuan perkreditan yang dimiliki oleh bank untuk menghasilkan pendapatannya, adapun perhitungannya adalah sebagai berikut :

Interest Income - Interest Expense

Total Loans

Dari data diketahui bahwa :

1. Periode Tahun 2011 interest income atau pendapatan bunga sebesar Rp. 5.645.589.597,06 dan interest expense atau biaya bunga sebesar Rp. 4.789.544.312,63 serta total loans atau kewajiban sebesar : Rp. 60.696.924.444,40.- Maka IML tahun 2011 adalah sebagai berikut :

$$
\begin{aligned}
\mathrm{IML} & =\frac{\text { Rp. } 5 \cdot 645 \cdot 589 \cdot 597,06-4 \cdot 789 \cdot 544 \cdot 312,63}{\operatorname{Rp} \cdot 60 \cdot 696 \cdot 924 \cdot 444,40}=0,014 \\
& =0,014 \times 100=1,4 \%
\end{aligned}
$$

Dari perhitungan ini diperoleh hasil bahwa tingkat rasio interest margin on loans periode tahun 2011 sebesar 1,4 \% artinya bahwa kemampuan pihak bank untuk memperoleh keuntungan dengan menggunakan seluruh kewajibannya sebesar 1,4\%. Dalam rasio ini semakin besar tingkat rasio, semakin besar keuntungan yang diperoleh pihak bank

2. Periode Triwulan I Tahun 2012 interest income atau pendapatan bunga sebesar : Rp. 986.569.566,91 dan interest expense atau biaya bunga sebesar : Rp. 693.182.758,10 serta total loans atau kewajiban sebesar Rp.61.488.794.624,40 Maka IML tahun 2012 triwulan I adalah sebagai berikut :

$$
\begin{aligned}
\mathrm{IML} & =\frac{\text { Rp. } 986 \cdot 569 \cdot 566,91-693 \cdot 182 \cdot 758,10=0,0047}{\text { Rp. } 61 \cdot 488 \cdot 794 \cdot 624,40} \\
& =0,0047 \times 100=0,047 \%
\end{aligned}
$$

Dari perhitungan ini diperoleh hasil bahwa tingkat rasio interest margin on loans periode triwulan I tahun 2012 sebesar 0,047 \% artinya bahwa kemampuan pihak bank untuk memperoleh keuntungan dengan menggunakan seluruh kewajibannya sebesar $0,047 \%$.

5. Rasio Likuiditas

a. Quick Ratio (QR) : Rasio ini untuk mengetahui kemampuan bank dalam membiayai kembali kewajibannya kepada para nasabah yang menyimpan dananya dengan aktiva lancar yang dimilikinya. Aktiva lancar terdiri dari : kas dan dana pihak ketiga (giro,tabungan dan deposito). Utang lancar yaitu total baki debet kredit yang diberikan oleh nasabah, adapun perhitungannya adalah sebagai berikut :

Aktiva Lancar

Utang Lancar/Kewajiban Jangka Pendek

Dari data diketahui bahwa : 
1. Periode Tahun 2011 aktiva lancar sebesar

Rp. 42.826.646.328,46 dan utang lancar atau kewajiban jangka pendek sebesar Rp.35.696.924.444,40 .- Maka QR tahun 2011 adalah sebagai berikut :

$$
\mathrm{QR}=\frac{\text { Rp. 42.826.646.328,46 }}{\text { Rp. 35.696.924.444,40 }}=1,199 \%
$$

Dari perhitungan ini dapat diketahui tingkat quick ratio periode tahun 2011 sebesar $1,199 \%$ artinya bahwa setiap utang lancar sebesar Rp.1 akan dijamin oleh aktiva lancar sebesar Rp.1,199. Dalam hal ini semakin tinggi tingkat rasio semakin besar pula likuiditasnya.

2. Periode Triwulan I Tahun 2012 aktiva lancar sebesar

Rp. 68.101.548.216,66 dan utang lancar atau kewajiban jangka pendek sebesar Rp.36.488.794.624,40. Maka QR tahun 2012 triwulan I adalah sebagai berikut :

$$
\mathrm{QR}=\frac{\text { Rp. 68.101.548.216,66 }}{\text { Rp. 36.488.794.624,40 }}=1,866 \%
$$

Dari perhitungan ini dapat diketahui tingkat quick ratio periode tahun triwulan I tahun 2012 sebesar 1,866 \% artinya bahwa setiap utang lancar sebesar Rp.1 akan dijamin oleh aktiva lancar sebesar Rp.1,866.

b. Loan to Deposit Ratio (LDR) : Rasio ini untuk mengetahui kemampuan bank dalam membayar kembali kewajiban kepada para nasabah yang telah menanamkan dananya. Adapun perhitungannya adalah sebagai berikut :

Utang Lancar/Kewajiban Jangka Pendek

Giro + Tabungan + Deposito

Dari data diketahui bahwa :

1. Periode Tahun 2011 utang lancar sebesar Rp. 35.696.924.444,40 dan dana pihak ketiga berupa giro,tabungan, dan deposito yaitu sebesar Rp.36.673.069.928,46 .- Maka LDR tahun 2011 adalah sebagai berikut :

$$
\mathrm{LDR}=\frac{\mathrm{Rp} \cdot 35 \cdot 696 \cdot 924 \cdot 444,40}{\text { Rp. 36.673.069.928,46 }}=0,973 \times 100=97,3 \%
$$

Dari perhitungan ini diperoleh hasil bahwa tingkat loan to deposits ratio (LDR) periode tahun 2011 sebesar 97,3\% artinya bahwa kemampuan pihak bank untuk memenuhi segala kewajiban utang lancarnya sebesar 97,3\%. Dalam rasio ini semakin besar tingkat rasio semakin baik tingkat likuiditasnya.

2. Periode Triwulan I Tahun 2012 utang lancar sebesar Rp. 36.488.794.624.,40 dan dana pihak ketiga berupa giro,tabungan, dan deposito yaitu sebesar Rp.66.549.807.216,66 . Maka LDR tahun 2012 triwulan I adalah sebagai berikut :

$$
\text { LDR } \frac{\text { Rp. } 36 \cdot 488 \cdot 794 \cdot 624,40}{\text { Rp. 66.549.807.216,66 }}=0,548 \times 100=54,8 \%
$$


Dari perhitungan ini diperoleh hasil bahwa tingkat loan to deposits ratio (LDR) periode triwulan I tahun 2012 sebesar 54,9 \% artinya bahwa kemampuan pihak bank untuk memenuhi segala kewajiban utang lancarnya sebesar 54,9\%.

Analisis Penilaian Tingkat Kesehatan Bank Pada PT. Bank Sulteng Capem Banggai Kepulauan.

Telah penulis kemukakan bahwa tingkat kesehatan bank pada PT. Bank Sulteng Capem Banggai Kepulauan ditetapkan berdasarkan penilaian terhadap laporan keuangan untuk tahun buku 2011 dan triwulan pertama tahun 2012, yang dinilai berdasarkan perhitungan perhitungan tingkat rasio-rasio bank yang meliputi : Rasio permodalan, Rasio effisiensi usaha, Rasio risiko usaha bank, Rasio rentabilitas, dan rasio likuiditas.

Dari hasil perhitungan - perhitungan tingkat rasio diatas, selanjutnya untuk menilai tingkat kesehatan bank pada PT. Bank Sulteng Capem Banggai Kepulauan periode tahun buku 2011, maka penulis terlebih dahulu merekap skor-skor yang telah diperoleh untuk masingmasing rasio, seperti terlihat pada tabel dibawah ini :

\section{Tabel 15}

Bobot Nilai Tingkat Kesehatan Bank Pada

PT. Bank Sulteng Capem Banggai Kepulauan Periode Tahun 2011

\begin{tabular}{|c|l|l|c|c|}
\hline No & \multicolumn{1}{|c|}{$\begin{array}{c}\text { Faktor Yang } \\
\text { Dinilai }\end{array}$} & \multicolumn{1}{|c|}{ Komponen Rasio } & $\begin{array}{c}\text { Tingkat } \\
\text { Rasio }\end{array}$ & $\begin{array}{c}\text { Bobot } \\
\text { Nilai }\end{array}$ \\
\hline 1. & Rasio Permodalan & a. Capital Adequacy Ratio & 1,539 & 4 \\
& & b. Current Liabilities to Equity & 38,2 & 10 \\
2. & \multirow{2}{*}{ Rasio Efisiensi Usaha } & a. Leverage Multiplier Ratio & 1,649 & 8,5 \\
& & b. Costs of Money & 9,9 & 10 \\
3. & \multirow{2}{*}{ Rasio Risiko Usaha } & a. Deposit Risk Ratio & 2,618 & 5,5 \\
& & b. Interest Rate Risk Ratio & 1,178 & 4 \\
4. & \multirow{2}{*}{ Rasio Rentabilitas } & a. Return on Assets (ROA) & 4,9 & 8,5 \\
& & b. Interest Margin on Loans & 1,4 & 4 \\
& \multirow{2}{*}{ Rasio Likuiditas } & a. Quick Ratio (QR) & 1,199 & 5,5 \\
& & b. Loan to Deposit Ratio/LDR & 97,3 & 10 \\
\hline & & \multicolumn{2}{|c|}{ Total Bobot } \\
\hline
\end{tabular}

Sumber : Data Olahan

Dari hasil total bobot yang diperoleh diatas yaitu sebesar 70 maka untuk menentukan tingkat kesehatan bank pada PT. Bank Sulteng Capem Banggai Kepulauan berdasarkan peringkat yang dikeluarkan Bank Indonesia, seperti yang terlihat pada tabel 15 .

Dari tabel predikat tersebut maka tingkat kesehatan bank pada PT. Bank Sulteng Capem Banggai Kepulauan periode tahun 2011 dengan perolehan total bobot sebesar 70 dikategorikan dengan predikat Cukup Sehat. Hal ini menggambarkan bahwa kinerja keuangan PT. Bank Sulteng Capem Banggai Kepulauan sudah cukup baik.

Selanjutnya dari hasil perhitungan tingkat masing-masing rasio untuk periode triwulan pertama tahun 2012 diperoleh hasil bobot nilai dari masing-masing rasio, seperti terlihat pada tabel dibawah ini : 
Tabel 16

Bobot Nilai Tingkat Kesehatan Bank Pada

PT. Bank Sulteng Capem Banggai Kepulauan Periode Tahun 2012

\begin{tabular}{|c|l|l|c|c|}
\hline No & \multicolumn{1}{|c|}{$\begin{array}{c}\text { Faktor Yang } \\
\text { Dinilai }\end{array}$} & \multicolumn{1}{|c|}{ Komponen Rasio } & Tingkat Rasio & $\begin{array}{c}\text { Bobot } \\
\text { Nilai }\end{array}$ \\
\hline 1. & Rasio Permodalan & a. Capital Adequacy Ratio & 2,658 & 5,5 \\
& & b. Current Liabilities to Equity & 22,3 & 10 \\
2. & \multirow{2}{*}{ Rasio Efisiensi Usaha } & a. Leverage Multiplier Ratio & 1,376 & 8,5 \\
& & b. Costs of Money & 4,4 & 4 \\
3. & \multirow{2}{*}{ Rasio Risiko Usaha } & a. Deposit Risk Ratio & 4,479 & 8,5 \\
& & b. Interest Rate Risk Ratio & 1,423 & 4 \\
4. & Rasio Rentabilitas & a. Return on Assets (ROA) & 0,52 & 2,5 \\
& & b. Interest Margin on Loans & 0,047 & 2,5 \\
5. & Rasio Likuiditas & a. Quick Ratio (QR) & 1,866 & 5,5 \\
& & b. Loan to Deposit Ratio/LDR & 54,8 & 10 \\
\hline & & \multicolumn{2}{|c|}{ Total Bobot } \\
\hline
\end{tabular}

Sumber : Data olahan

Dari hasil total bobot yang diperoleh diatas yaitu sebesar 61 maka untuk menentukan tingkat kesehatan bank pada PT. Bank Sulteng Capem Banggai Kepulauan periode triwulan pertama tahun 2012 berdasarkan peringkat yang dikeluarkan Bank Indonesia, seperti yang terlihat pada tabel 16 maka tingkat kesehatan bank pada PT. Bank Sulteng Capem Banggai Kepulauan periode triwulan pertama tahun 2012 dengan perolehan total bobot sebesar 61 dikategorikan dengan predikat Cukup Sehat. Hal ini menggambarkan bahwa kinerja keuangan PT. Bank Sulteng Capem Banggai Kepulauan sudah cukup baik.

Berikut ini perbandingan tingkat kesehatan bank Pada PT. Bank Sulteng Capem Banggai Kepulauan untuk periode tahun buku 2011 dan periode triwulan I tahun 2012, seperti terlihat pada tabel 17 dibawah ini :

Tabel. 17

Perbandingan Tingkat Kesehatan Bank Pada PT. Bank Sulteng Capem Banggai Kepulauan Periode Tahun 2011 dan Triwulan I Tahun 2012

\begin{tabular}{|c|c|c|c|c|c|c|c|}
\hline \multirow{2}{*}{$\begin{array}{l}\mathbf{N} \\
\mathbf{O}\end{array}$} & \multirow{2}{*}{$\begin{array}{c}\text { Faktor Yang } \\
\text { Dinilai }\end{array}$} & \multirow{2}{*}{$\begin{array}{l}\text { Komponen } \\
\text { Rasio }\end{array}$} & \multicolumn{2}{|c|}{ Tahun 2011} & \multicolumn{2}{|c|}{ Tri.I 2012} & \multirow[b]{2}{*}{ KET } \\
\hline & & & $\begin{array}{c}\text { Tingkat } \\
\text { Rasio }\end{array}$ & $\begin{array}{c}\text { Bobot } \\
\text { Nilai }\end{array}$ & $\begin{array}{c}\text { Tingkat } \\
\text { Rasio }\end{array}$ & $\begin{array}{c}\text { Bobot } \\
\text { Nilai }\end{array}$ & \\
\hline \multirow[t]{2}{*}{1} & Rasio Permodalan & a. Capital Adequacy Ratio & 1,539 & 4 & 2,658 & 5,5 & $\mathrm{~N}$ \\
\hline & & b. Current Liabilities to Equity & 38,2 & 10 & 22,3 & 10 & $\mathrm{~T}$ \\
\hline \multirow[t]{2}{*}{2} & Rasio Efisiensi Usaha & a. Leverage Multiplier Ratio & 1,649 & 8,5 & 1,376 & 8,5 & $\mathrm{~T}$ \\
\hline & & b. Costs of Money & 9,9 & 10 & 1,4 & 4 & $\mathrm{~T}$ \\
\hline \multirow[t]{2}{*}{3} & Rasio Risiko Usaha & a. Deposit Risk Ratio & 2,618 & 5,5 & 4,479 & 8,5 & $\mathrm{~N}$ \\
\hline & & b. Interest Rate Risk Ratio & 1,178 & 4 & 1,423 & 4 & $\mathrm{~N}$ \\
\hline \multirow[t]{2}{*}{4} & Rasio Rentabilitas & a. Return on Assets (ROA) & 4,9 & 8,5 & 0,52 & 2,5 & $\mathrm{~T}$ \\
\hline & & b. Interest Margin on Loans & 1,4 & 4 & 0,047 & 2,5 & $\mathrm{~T}$ \\
\hline \multirow[t]{3}{*}{5} & Rasio Likuiditas & a. Quick Ratio (QR) & 1,199 & 5,5 & 1,866 & 5,5 & $\mathrm{~N}$ \\
\hline & & b. Loan to Deposit Ratio/LDR & 97,3 & 10 & 54,8 & 10 & $\mathrm{~T}$ \\
\hline & \multicolumn{2}{|c|}{ Jumlah Total Bobot Nilai } & & 70 & & 61 & \\
\hline
\end{tabular}

Sumber : Data Olahan 
Berdasarkan pada tabel 17 perbandingan tingkat kesehatan bank tersebut diatas, jika dilihat dari tingkat perkembangan rasio tanpa melihat bobot nilai, pada periode tahun 2011 dengan periode triwulan I tahun 2012, terlihat adanya kenaikan dan penurunan tingkat rasio. Sampai dengan triwulan I tahun 2012 terjadi penurunan yang signifikan

\section{Kesimpulan Dan Saran}

\section{Kesimpulan}

Berdasarkan hasil penelitian yang penulis peroleh, maka dapat ditarik kesimpulan sebagai berikut :

1. Dari hasil perhitungan dan bobot nilai terhadap masing-masing tingkat rasio untuk periode tahun 2011 diperoleh hasil sebagai berikut :

Berdasarkan hasil perhitungan terhadap masing-masing tingkat rasio serta bobot penilaiannya maka diperoleh total bobot nilai sebesar 70 Dari hasil ini maka penilaian tingkat kesehatan bank pada PT. Bank Sulteng Capem Banggai Kepulauan untuk periode tahun 2011 dikategorikan dengan predikat Cukup Sehat.

2. Dari hasil perhitungan dan bobot nilai terhadap masing-masing tingkat rasio untuk periode triwulan pertama tahun 2012 diperoleh hasil sebagai berikut :

Berdasarkan hasil perhitungan terhadap masing-masing tingkat rasio serta bobot penilaiannya maka diperoleh total bobot nilai sebesar 61 Dari hasil ini maka penilaian tingkat kesehatan bank pada PT. Bank Sulteng Capem Banggai Kepulauan

\section{Daftar Pustaka}

Arifin, Johar, 2004, Analisis Laporan Keuangan Berbasis Komputer, PT. Elex Media Komputindo, Jakarta. untuk rasio return on assets (ROA) mencapai besaran $842 \%$, rasio cost of money (CM) mencapai $607 \%$ dan loan to deposits ratio (LDR) terjadi penurunan sebesar 77,5 \%. Sedangkan kenaikan terjadi pada capital adequacy ratio (CAR) sebesar 72,7 \% , deposits risk ratio (DRR) sebesar $71 \%$, dan quick ratio terjadi kenaikan sebesar 55,6\%.

untuk periode triwulan pertama tahun 2011 dikategorikan dengan predikat Cukup Sehat.

\section{B. Saran}

Berdasarkan hasil perhitungan dalam penelitian ini bahwa perolehan bobot nilai CAR tahun 2010 rendah yaitu sebesar 4 hal ini disebabkan tingkat rasio yang rendah yaitu mencapai $1,539 \%$, sedangkan triwulan pertama tahun 2011 bobot nilai ROA juga sangat rendah yaitu sebesar 2,5, hal ini disebabkan tingkat rasio ROA yang sangat rendah yaitu hanya mencapai $0,52 \%$, untuk mengatasi hal-hal tersebut, maka penulis menyarankan :

1. PT. Bank Sulteng Capem Banggai Kepulauan lebih bekerja keras untuk mencari nasabah sebanyak-banyaknya dengan cara melahirkan produk-produk unggulan agar masyarakat tertarik untuk menyimpan dananya pada PT. Bank Sulteng Capem Banggai Kepulauan.

2. Untuk memperbesar tingkat rasio ROA, PT. Bank Sulteng Capem Banggai Kepulauan untuk lebih efisiensi dan efektif dalam pengelolaan dananya serta lebih meningkatkan pendapatan operasionalnya.

Arthesa, Handiman, 2006. Bank Dan Lembaga Keuangan, Edisi Kedua, Bumi Aksara, Jakarta.

Husnan Suad, Enny Pudjiastuti, 1998, Dasardasar Manajemen Keuangan, Edisi ke 2, UPP AMPYKPN, Yogyakarta. 
Munawir,S, 1995, Analisa laporan Keuangan, Edisi keempat, LIBERTY, Yogyakarta.

Nasution MA, 2002, Metode Research, Edisi I, Cetakan 5, Bumi Aksara, Jakarta.

Riyanto, Bambang, 1999, Dasar-dasar Pembelanjaan Perusahaan, Edisi 4, BPFE, Yogyakarta.

Sawir, Agnes, 2001. Analisis Kinerja Keuangan dan Perencanaan Keuangan Perusahaan. Cetakan II.Gramedia Pustaka Utama.Jakarta
Syafaruddi, Alwi, 1993, Alat-alat Analisis dalam Pembelanjaan, Edisi 3, ANDI OFFSET, Yogyakarta.

Syamsuddin, Lukman, 1998, Manajemen Keuangan Perusahaan, Cetakan 4, PT. Raja Grafindo Persada, Jakarta.

Swasta Basu, Sukotjo Ibnu, 1998, Pengantar Bisnis Modern, (Pengantar Ekonomi

Perusahaan Modern), Cetakan 6, LIBERTY, Yogyakarta.

Sutrisno, 2001, Manajemen Keuangan, Edisi I, Cetakan Kedua, Ekonosia, Yogyakarta.

Triandaru, Budisantoso.2006, Bank Dan Lembaga Keuangan Lain.Edisi Kedua,Salemba Empat.Jakarta 
